\title{
Use and preservation methods of bone grafts in small animals
}

\author{
Rafael Garabet Agopian 1* \\ Brunna Duarte Braz de Oliveira ${ }^{1}$ \\ Kátia Oliveira Pimenta Guimarães ${ }^{2}$ \\ Marcos Vinicius Mendes Silva ${ }^{2}$ \\ Jéssica Borghesi ${ }^{2}$ \\ Rodrigo da Silva Nunes Barreto ${ }^{2}$ \\ Phelipe Oliveira Favaron ${ }^{2}$ \\ ${ }^{1}$ Santo Amaro University \\ Rua Professor Enéas de Siqueira Neto, 340, CEP 04829-300, São Paulo - SP, Brazil \\ ${ }^{2}$ University of São Paulo, School of Veterinary Medicine and Animal Science, Department of Surgery \\ São Paulo - SP, Brazil \\ * Autor para correspondência \\ rafael.agopian@gmail.com
}

Submetido em 14/10/2015

Aceito para publicação em 09/05/2016

\section{Resumo}

Uso e preservação de métodos de enxertos ósseos em pequenos animais. $O$ presente estudo descreve as principais características dos enxertos ósseos em pequenos animais. Enxertos ósseos são tecidos avasculares e que facilitam a produção de novas células ósseas com capacidade osteogênica e osteoindutiva, facilitando a diferenciação celular e suporte para a medula óssea. O transplante do enxerto é sucedido por três fases: osteogênese, levando a formação de novo osso; osteoindução, que é a diferenciação das células; e osteocondução, o processo e crescimento de células mesenquimais e capilares, resultando na formação da medula óssea. Os enxertos ósseos podem ser provenientes de áreas esponjosas, corticais, esponjo-cortical, cartilagem ou medula óssea. Eles também podem ser classificados quanto a sua origem, sendo eles autógeno (proveniente do mesmo indivíduo), alógeno (proveniente de outro indivíduo da mesma espécie), ou mesmo xenólogo (proveniente de indivíduo de outra espécie).

Palavras-chave: Enxerto ósseo; Osso; Pequenos animais; Reconstrução

\section{Abstract}

The present review describes the main characteristics of bone grafts used in small animals. Bone grafts are tissues without vasculature, which facilitate the production of new bone cells with osteogenic and osteoinductive factors that lead to the differentiation of cells and structural support for bone marrow. The transplant of a graft is followed by three stages: osteogenesis, or the formation of new bone; osteoinduction, which is the differentiation of cells; and osteoconduction, the process of growth of mesenchymal cells and capillaries that results in new bone formation. The composition of bone grafts may include spongy bone, cortical bone, cortical-spongy 
bone, cartilage or bone marrow. Grafts can also be classified according to their origin, being autogenous tissue when they are transplanted from the same individual, allogenous (homologous) when originating from another individual of the same species, and xenogenous when obtained from a different species.

Key words: Bone; Bone graft; Reconstruction; Small animals

\section{Introduction}

Orthopedic injuries are very common occurrences in the clinical routine of small animals. In this regard, a large proportion of these problems can be surgically resolved and long bone fractures are among the most common surgeries (BALTHAZAR; PAPPAS, 1984). Bone grafts and implants are emerging as the main alternatives to treat bone tumors, long bone fractures and nonunions (WADSWORTH; HENRY, 1976; ALIEVI et al., 2007). In addition, there is a constant interest in the development of veterinary and human biobanking in order to provide readily available tissue grafts of high quality and safety for reconstructive surgeries (INNES; MYINT, 2011). Moreover, the field of biobanking is playing critical roles in tissue sample collection and processing in order to ensure the integrity of the samples and better results (HOSTETTER et al., 2014).

Currently, several materials have been described for the repair of fractures, but the best source for obtaining a graft is from the same individual. Autograft tissue is taken from and transplanted to the same individual, and is a widely used technique due to its histocompatibility with the immune system, which reduces the occurrence of rejection and achieves satisfactory results (ALIEVI et al., 2007). However, disadvantages have been observed, such as limited availability of tissue, prolonged surgical time that increases the chance of bleeding, infection and chronic pain in the donor (GIANNOUDIS et al., 2007). In addition, these tissues may be used as allogenic grafts, which are transplanted to another individual of the same species and allow for the creation of a bone bank that eliminates the need to look for an available donor (FERREIRA et al., 2012).

The present study describes the main characteristics and classifications of bone grafts used in veterinary medicine, especially in small animal clinics.

\section{History}

The first successful bone transplant was reported in 1668. The Dutch surgeon Van Meekeren used a xenogenic bone graft of a canine skull in the skull of a Russian soldier and obtained complete integration (WEIGEL, 1993).

The first report of the use of a graft in veterinary medicine was in 1976. Two feline cortical allograft bones were used. In the first feline they used a fresh graft, and in the second feline, which had a comminuted femur fracture, they used a frozen graft. The interventions were successful, with satisfactory bone healing (WADSWORTH; HENRY, 1976).

Since then a lot of work has been done using various types of conservation means and grafts in the treatment of orthopedic injuries. An experimental study in rabbits was made by comparing the use of organic and inorganic grafts in the repair of radio fractures (MIRANDA et al., 2005). Another study successfully corrected femoral bone defects in dogs using homologous cortical grafts preserved in honey (AMENDOLA et al., 2003). Also, xenografts have been used for osteosynthesis of humeral fractures in domestic pigeons (Columba livia), using feline metatarsal grafts (GAIGA; SCHOSSLER, 2003).

\section{Definition}

Grafts or implants stand out as a treatment for orthopedics injuries applied in the treatment of dogs and cats. The term graft is associated with the transplantation of viable material or living tissue, while implant is associated with non-living or non-biological tissue. Both terms refer to a non-vascularized tissue that can be transplanted to another region in the same individual or to different individuals (STEVENSON, 1998).

Bone grafts improve the ability of bone healing, providing a source of osteogenic, osteoinductive and 
osteoconductive factors. Depending of the type used, a graft can also act as mechanical support (GOLDBERG; STEVENSON, 1987).

When a tissue is removed from a part of the body and is grafted to another site of the same individual, it is called an autogenous graft. This type of graft has the advantage of having a higher osteogenic capacity and histocompatibility with the host's immune system, so rejection doesn't occur (AMENDOLA et al., 2008).

An allograft, or homologue tissue, is obtained from an individual and transplanted to another individual of the same species. The importance of maintaining a bone tissue bank was demonstrated in an orthopedic routine (ROOS et al., 2000). These authors studied allografts, which proved to be advantageous in several respects. One of the advantages is this graft type provides a sufficient amount and variety of material to the orthopedist, and does not require additional surgeries due to biocompatibility.

An allograft is bone without cellular activity that was subjected to a preservation medium, such as freezing, irradiation, honey or lyophilization (FOSSUM, 2007; FEREIRA et al., 2012).

Transplanting tissue from an individual to a different species is called xenograft transplantation. This type is used less because it leads to an exacerbated antigenic response (MILLIS; MARTINEZ, 2007; ISOLA et al., 2011).

The behavior of autogenous bone and xenogenous bone for tissue repair was compared in $15 \mathrm{dogs}$, with the goal of stimulating the use of xenogenous grafts (SANTOS et al., 2005). Based on clinical and radiographic results, the authors concluded that the use of xenografts was viable and did not show any inferior results in relation to autografts.

Due to the limitations of the bone grafts mentioned above, there are alternative biomaterials such as a temporary matrix that provides a great environment and appropriate architecture for bone proliferation (MARTIN; RIBOLDI, 2010). For example, there are the following types of biomaterials: polymers, which can be natural or synthetic and are selected according to their physical and mechanical properties and degradation time, which is determined according to the intended application (LEE et al., 2006); ceramic, which is obtained from a non-natural material and is strong with low deformability, but is also fragile (LARSSON, 2010); metal splints, which are used as porous metal bone-mimicking structures that resist corrosion, are biocompatible, non-biodegradable and highly durable, but because of their rigidity there is no adequate adhesion to the bone implant (LUCARELLI et al., 2004); compounds, the combination of two materials in the same procedure that produces a better material (MATASSI et al., 2011); scaffolds are used to provide a suitable environment for isolated cells in vitro (because these cells require a three-dimensional support since they do not have the conformation of bone), allowing cell aggregation, proliferation and differentiation that leads to the deposition of a new bone extracellular matrix (COSTA-PINTO et al., 2011); and BMP, a morphogenetic protein from bone that also uses scaffolds and has osteoinductive action and an ability to induce mesenchymal cells to transform into progenitor cells that produce bone (MARX; WONG, 1987; EINHORN et al., 1995).

\section{Classification}

Bone grafts can be classified according to their morphological structure: 1) spongy, composed of trabecular bone, has high cellularity and can be collected from the metaphysis of long bones; 2) cortical, composed of cortical bone, has little cellularity, can be collected from diaphysis of long bones and provides structural support; 3) corticospongy, consists of cortical and spongy bone, and can be collected from the rib or the iliac wing; and 4) osteochondral, which has articular cartilage (ALIEVI et al., 2007; FOSSUM, 2007; MILLIS; MARTINEZ, 2007; AMENDOLA et al., 2008; FERREIRA et al., 2012).

\section{Functions}

The main functions of the grafts are the following: 1) osteogenesis, or production of new bone, where the bone may be formed from or around the graft and originates from cells that have survived the transfer or 
from the cells of the receptor; 2) osteoinductive factors, which make the differentiation of undifferentiated mesenchymal cells to bone cells; 3) osteoconductive matrix, which acts as a support for bone growth (the growth of capillaries, perivascular tissue and osteoprogenitor cells are involved in this process and there is migration of osteoclasts and osteoblasts); and 4) mechanical support to the receptor tissue (GOLDBERG; STEVENSON, 1987; STEVENSON, 1998; ALIEVI et al., 2007; FERREIRA et al., 2012).

\section{Osteogenesis}

Refers to bone formation promoted by the donor cells, by transfer of osteoclasts and osteoblasts to a particular region, or growth promotion by host cells. In fresh grafts osteogenesis occurs by viable cell transplantation (STEVENSON, 1998; ALIEVI et al., 2007; MILLIS; MARTINEZ, 2007).

A spongy graft has a higher potential than a cortical graft in bone formation because its surface is covered with coatings of quiescent cells, undifferentiated mesenchymal cells (osteoprogenitor cells) and active osteoblasts. Osteoprogenitor cells are found in bone marrow, fixed in the spongy bone (STEVENSON, 1998, MILLIS; MARTINEZ, 2007; FERREIRA et al., 2012).

\section{Osteoinduction}

Osteoinduction is one of the main properties attributed to bone grafts. Mesenchymal cells are induced to differentiate into osteoblasts and chondroblasts, after contact with the bone matrix. These cells proliferate and produce a mineralized matrix (MILLIS; MARTINEZ, 2007). This differentiation process is modulated by various proteins, including bone morphogenetic protein (BMP), which stimulate the recruitment of osteoprogenitor cells for bone formation (SANTOS et al., 2005), tissue growth factor (TGF), and prostaglandins that are produced inside different cells and stored in elements such as platelets (MILLIS; MARTINEZ, 2007; ZABEU; MERCADANTE, 2008; FERREIRA et al., 2012).

Both spongy and cortical bones have morphogenetic proteins in their bone matrix. However, spongy bones are more exposed to the protein matrix than cortical bones (MILLIS; MARTINEZ, 2007; ZABEU; MERCADANTE, 2008; FERREIRA et al., 2012).

\section{Osteoconduction}

Osteoconduction is a process in which the graft promotes the positioning of a structure on the surface of a new bone, for the migration and distribution of cells involved in vascularization and bone healing (KAVEH et al., 2010). Allografts and synthetic materials can serve as osteoconductive tissues (STEVENSON, 1998). The osteoconductive property of a graft or implant depends on its architecture. In spongy tissue osteoconduction is faster than cortical tissue due to its high porosity (FERREIRA et al., 2012).

\section{Indications and contraindications}

The two main indications for bone grafts are the enhancement of healing and restoration of bone loss through a trauma or a surgical resection.

In comminuted, contaminated and infected fractures, which require rapid synthesis of new bone, the use of an autogenous spongy graft is indicated, due to the high potential for revascularization, since the surrounding soft tissue is viable and appropriately vascularized. However, these are not weight-bearing grafts for the new bone (STEVENSON, 1998).

Cortical allografts are indicated for severe fractures, in cases of non-union, to increase or improve joint congruency, and for bone tumors; they are contraindicated in cases of exposed fractures, infected fractures and situations that lack rigid internal fixation of the graft (ALIEVI et al., 2007; FERREIRA et al., 2012).

There are also certain disadvantages in using grafts, such as limited sources of autogenous grafts, immunemediated rejection of allografts, infectious agents that can be transmitted with the use of allografts, fractures, pain, seromas and bleeding (FOSSUM, 2007). 


\section{Collection and preparing}

The ideal donor must be a young animal, free of pre-existing bacterial, viral, metabolic or neoplasic disease. Bones can be removed from the donor in deep plane of anesthesia (WADSWORTH; HENRY, 1976; STEVENSON, 1998; FERREIRA et al., 2012).

Collection should follow strict asepsis, which can be made with a degerming solution, such as thimerosal solution or povidone iodine solution, and must be performed within two hours after death of the donor. Soft tissues, ligaments and capsular insertions must be removed, and then the graft must pass a microbiological test (PINTO JR et al., 1995; FEOFILOFF; GARCIA, 1996).

\section{Spongy bone graft}

This type of graft can be collected from any long bone metaphysis. The most commonly used are the proximal humerus, tibia and iliac wing, which contain large amounts of spongy bone (DELLOYE et al., 1985; SANTOS; RAHAL, 2004). To collect a bone graft of the proximal humerus, a craniolateral incision of the skin and subcutaneous tissue is made, followed by an incision into to the acromial part of the deltoid muscle, which exposes the proximal metaphysis. With a Steinmann pin or grooved drill, the bone cortex is penetrated and the graft is collected with the assistance of a bone curette, inserting the curette in the same caudomedial direction (SCHENA III, 1983; JOHNSON; HULSE, 2002). To collect the medial proximal tibia, an incision is made below the tibial plateau between the collateral ligament and tibial tuberosity. Using blunt dissection, the subcutaneous tissue and the sartorius and the gracilis muscles in their insertion are separated. Next, the cortex is punched up with a Steinmann pin, drill or drill bit, and the cancellous bone graft is collected with a curette (FOX, 1984). For the iliac crest, the surgery begins with the incision of the skin and subcutaneous tissue. A section of the facial origin of the gluteus maximus muscle is made, elevating and retracting the muscle ventrally. To prevent possible injury to the medial cortex an opening is made in the outer cortex with the help of an Osteotome and a hammer, Steinmann pin or trephine, and the cancellous bone is removed with a curette (SCHENA III, 1983).

The first stage after graft incorporation is inflammation. Inflammatory changes occur within minutes to hours after the surgical procedure. The second and third stages are revascularization and osteogenesis, respectively. As the spongy bone has high porosity, vessels, osteoblasts and osteoclast precursors infiltrate the graft from the periphery toward the center. During revascularization, mesenchymal cells differentiate into osteogenic cells (FOSSUM, 2007; FERREIRA et al., 2012). The fourth stage is osteoconduction. During this stage the osteoclasts gradually reabsorb the bone; the nuclei of necrotic bone are captured and then replaced by new bone. Osteoconduction and remodeling can take several months for a porous autograft procedure. The final incorporation rarely occurs in spongy autografts, because they are usually completely reabsorbed and replaced by a new bone (STEVENSON, 1998).

\section{Cortical graft}

These implants primarily provide mechanical support and contribute to osteoinduction and osteoconduction. They are used to repair large diaphyseal defects resulting from trauma or resection of a tumor (GOLDBERG; STEVENSON, 1987).

The cortical graft is usually collected from the diaphysis of long bones. First, the area to be collected is defined and in a sequence the graft is carefully removed with the aid of a saw or osteotome. The grafts can be removed with the aid of an electric saw or for a less traumatic effect an oscillating saw or a cutting pneumatic drill; irrigation is performed with physiological saline at room temperature to prevent excessive heat (HUNG, 2012).

The microarchitecture is quite compact, formed by intensely mineralized overlapping blades, and is arranged around the Haversian canals. This explains why the bone is very dense, and because of this revascularization, resorption and reossification are slower (GOLDBERG; STEVENSON, 1987). During the resorption phase, the graft is weaker than the host bone due to incomplete incorporation of the graft. The complete incorporation 
of the graft cortical may take months or years to occur, with greater bone formation in the proximal and distal portions. Its activity is greater 5 to 6 months after surgery. If during the inflammatory phase antigenic material remains, allograft rejection may occur due to a immune cellular response (MILLIS; MARTINEZ, 2007).

The successful incorporation of the grafts requires infection-free cortical areas, with adequate blood supply and rigid fixation. Other factors that may affect the incorporation of cortical bone are immunogenicity and the preservation method. Graft preservation methods have been studied to decrease immunogenicity (ALIEVI et al., 2007).

\section{Bone substitutes}

The replacement of bone occurs through the exchange of the bone structure, restoration or filling from a loss of bone substance, in order to provide the migration, proliferation and differentiation of bone cells that stimulates vascularization by using the natural response of the body against the injury (ROMAGNOLI; BRANDI, 2014).
Mechanical devices and transplantation of various types of tissue are used in reconstruction techniques and surgical replacement. However, it is worth emphasizing that the biomedical devices used in reconstructive surgery can not guarantee the total replacement of the biological features of the tissue in question, making it impossible to prevent its progressive deterioration (TABATA, 2009).

The bone substitute material may be natural or synthetic. It should be biocompatible, bioabsorbable, with osteoinductive and osteoconductive properties (DELLOYE et al., 1985).

Some studies have reported several materials for the repair of bone tissue, such as the use of castor plant polymer added to bone marrow cells (JUNQUEIRA; CARNEIRO, 2013), bone morphogenetic protein (AMENDOLA et al., 2008), and demineralized bone matrix (STEVENSON, 1998). This variety of options is very useful to the surgeon, due to the different characteristics (BRYDONE et al., 2010) (Figure 1).

FIGURE 1: Radiographic image of humeral fractures in birds. (A) the immediate postoperative period; (B) 60 days after surgery. (A) the bone fracture, with the presence of humeral discontinuity (arrow) and bone graft (black asterisk) immediately after surgery. (B) significant bone proliferation (arrowhead) and the bone graft still present (white asterisk) after 60 days of surgery.
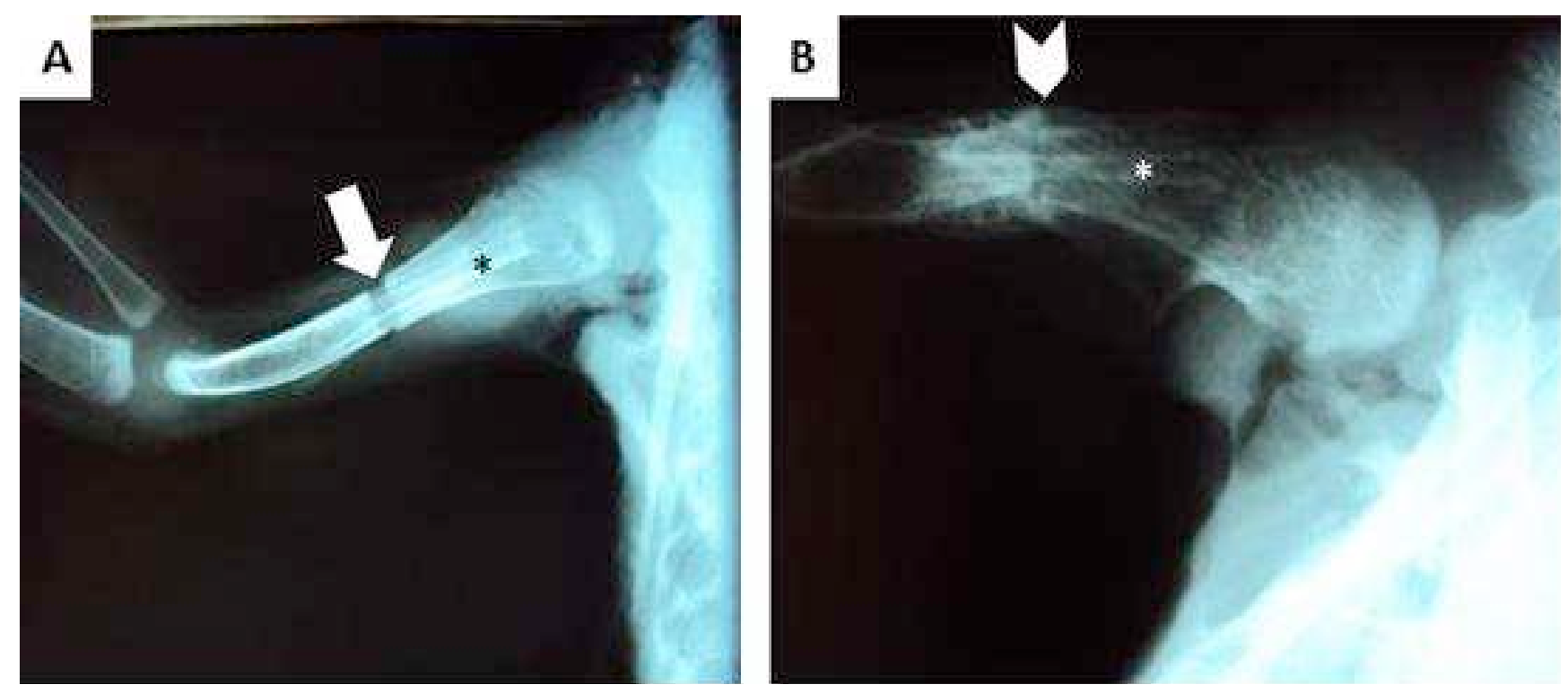


\section{Means of conservation}

Figure 2 shows an overview of both preparation and conservation time for bones using honey, glycerin, sugar, and liquid nitrogen as conservation solutions.

\section{Honey}

Honey has been used since ancient times as a substance capable of preserving tissues. One study evaluated the use of canine bone preserved in honey as an implant in bone defects and concluded that honey may be suitable as a bone preservative (AMENDOLA et al., 2008). In another study, it was found that feline metatarsal xenografts preserved in honey and placed on the humeral osteosynthesis of domestic pigeons were highly feasible and there was no rejection of the grafts (GAIGA; SCHOSSLER, 2003).

\section{Glycerin}

Glycerin is a handy, economical and aseptic method, acting as a fixative and dehydrating agent, and is not only suitable for the preservation of bones, but also of different biological materials (GIOSO et al., 2002; AMENDOLA et al., 2008).

The osteoinduction function of bone fragments stored in 98\% glycerol was tested, and it was concluded that the osteoinductive activity was preserved through the implant (CAVASSANI et al., 2001).

\section{Sugar}

The presence of this substance increases osmotic pressure, creating unfavorable conditions for bacterial growth. Bony rib implants were retained in crystal sugar in natura, or a supersaturated solution of sugar (300\%), for at least 30 days and successfully reconstructed experimental bone defects in the ribs of felines (RAPPETI et al., 2007). There has not been a chronological study in relation to the conservation time of tissues using sugar. Therefore, we expect that this time could be around 6 months, considering the similar physiochemical characteristics between honey and sugar.

FIGURE 2: Preparation and conservation time for bones using honey, glycerin, sugar, and liquid nitrogen as conservation solutions.

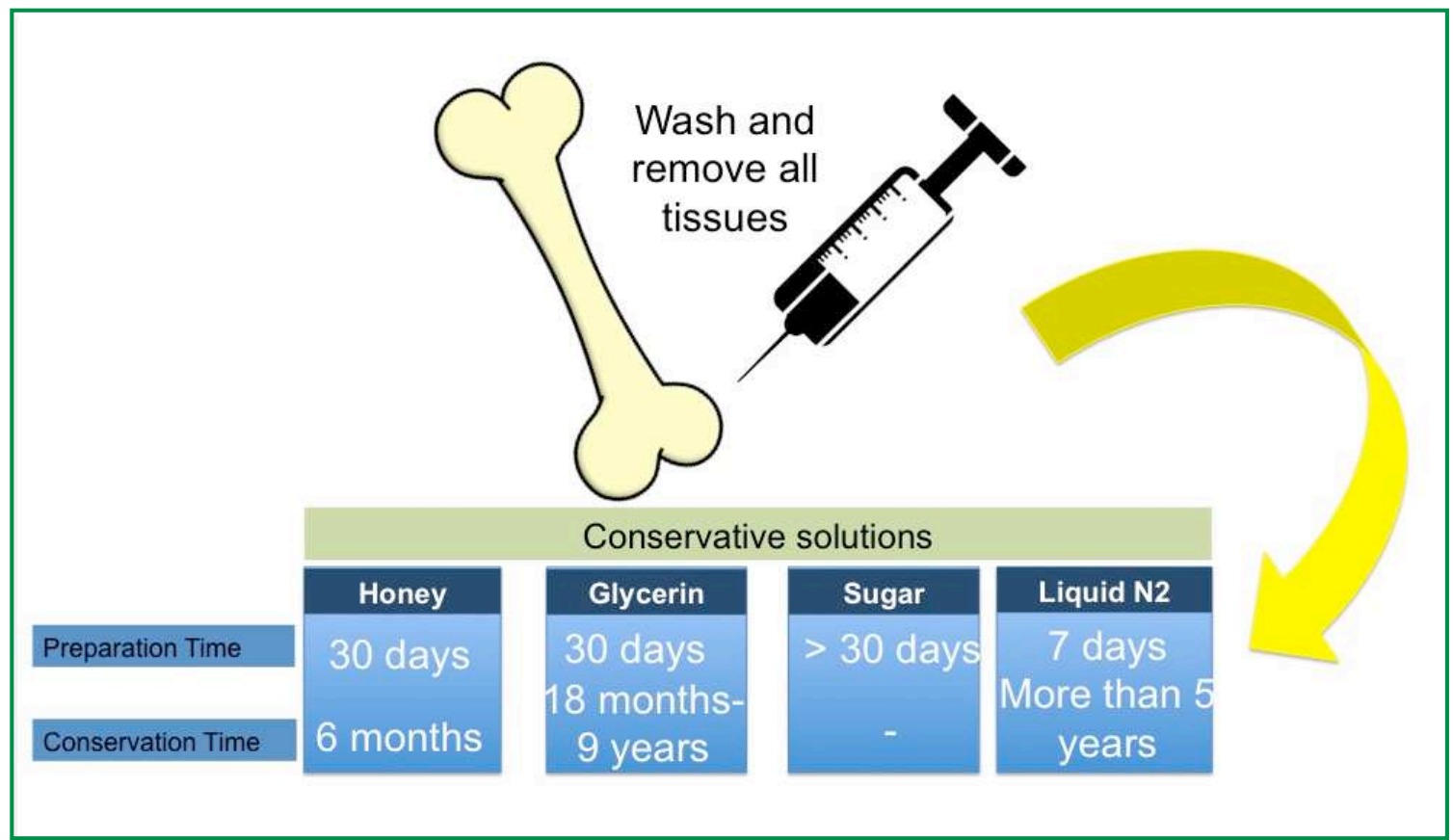




\section{Liquid nitrogen}

The advantages of liquid nitrogen are its low cost, small need of specialized equipment, simplicity of the technique and the decreased chances of immunogenic reactions and disease transmission. In general, the time of preparation is about 7 days (TANAKA et al., 2003) and cryopreservation allows for storage for up to five years if the samples are stored in liquid nitrogen vapor (INNES; MYINT, 2011). Allograft cortical bone was subjected to freezing in liquid nitrogen, which was was found to be a suitable method for the preservation of the limb locomotor and obtained $100 \%$ of incorporation (ALBUQUERQUE, 2012).

\section{Lyophilization}

The lyophilization technique has been hardly used in the area of veterinary medicine due to the need for specific, expensive equipment (ZASACKI, 1991). This technique involves dehydrating previously degreased bone (LUCHESE; DECHECHI, 2003).

Technically, this allows the obtainment of biocompatible and sterile material that can be kept at room temperature, because after lyophilization the material loses its ability to become contaminated and degraded (KAKIUCHI et al., 1996).

\section{Conclusion}

The use of grafts in veterinary medicine serve as effective and safe treatments in bone defects because they have properties that promote the formation of new bone or induce differentiation of cells to form new bone. Besides grafts, bone substitutes have also been studied, which have the same properties; both decrease surgery time and postoperative morbidity. When cortical grafts collected from bone banks are used, they are quickly incorporated into the host bone. They also potentiate the healing in trauma and do not require expensive equipment or a complicated procedure compared to spongy grafts. Some grafts require a storage medium to reduce their immunogenicity and to provide surgeons access to the grafts when necessary. Thus, several studies mention the use of bone banks in veterinary medicine as a practical and functional service, which has advantages and benefits. In this regard, there is an expectation that developing protocols in order to ensure the quality of tissue samples during collection and conservation will define new methods for good clinical practice leading to better results. Veterinary medicine has made advances in bone grafting techniques over the years, and has shown that these techniques can be applied both to pets and other species, such as ruminants and wild animals.

\section{References}

ALBUQUERQUE, P. B. Aloenxerto ósseo cortical desvitalizado com nitrogênio liquido: estudo experimental em ovelhas. 2012. 52 f. Dissertação (Mestrado em Morfologia, Cirurgia e Patologia Animal) - Universidade Federal do Rio Grande do Sul, Porto Alegre. 2012.

ALIEVI, M. M.; SCHOSSLER, J. E. W.; GUIMARÃES, L. D.; OLIVEIRA, A. N. C. DE; TRAESLEL, C. K.; FERREIRA, P. A. Implante ósseo cortical alógeno conservado em mel na reconstrução de falha óssea diafisária em fêmur de cães: avaliação clínica e radiográfica. Ciência Rural, Santa Maria, v. 37, n. 2, p. 450-457, 2007.

AMENDOLA, G. F.; ILHA, M.; BERGER, R.; STEDILE, R.; SCHOSSLER, J. E. Correção de defeito ósseo femural em cães utilizando implante cortical homólogo conservado em mel. Acta Cirurgica Brasileira, São Paulo, v. 18, n. 4, p. 302-307, 2003.

AMENDOLA, G. F.; RAISER, A. G.; SOARES, J. M. D.; BECKMANN, D. V. Aspectos biomecânicos compressivos de diáfises femorais caninas conservadas em glicerina a $98 \%$ ou em mel. Ciência Rural, Santa Maria, v. 38, n. 5, p. 1341-1345, 2008.

BALTHAZAR, D. A.; PAPPAS, A. M. Acquired valgus deformity of the tibia in children. Journal of Pediatric Orthopedics, New York, v. 4, n. 5, p. 538-541, 1984.

BRYDONE, A. S.; MEEK, D.; MACLAINE, S. Bone grafting, orthopaedic biomaterials, and the clinical need for bone engineering. Proceedings of the Institution of Mechanical Engineers, Part H: Journal of Engineering in Medicine, London, v. 224, n. 12, p. 1329-1343, 2010.

CAVASSANI, M. M.; MORAES, J. R. E.; PADILHA FILHO, J. G. Função osteoindutora de fragmentos ósseos conservados em glicerina a 98\%: estudo experimental em ratos. Ciência Rural, Santa Maria, v. 31, n. 3, p. 445-448, 2001.

COSTA-PINTO, A. R.; REIS, R. L.; NEVES, N. M. Scaffolds based bone tissue engineering: the role of chitosan. Tissue Engineering: Part B, New Rochelle, v. 17, n. 5, p. 331-348, 2011

DELLOYE, C.; HEBRANT, A.; MUNTING, E.; PIRET, L.; COUTELIER, L. The osteoinductive capacity of differently $\mathrm{HCl}$ decalcified bone alloimplants. Acta Orthopaedica Scandinavica, København, v. 56, n. 4, p. 318-322, 1985.

EINHORN, T. A.; MAJESKA, R. J.; RUSH, E. B.; LEVINE, P. M.; HOROWITZ, M. C. The expression of cytokine activity by fracture 
callus. Journal of Bone and Mineral Research, New York, v. 10, n. 8, p. 1272-1281, 1995.

FEOFILOFF, E. T.; GARCIA, R. Técnica de obtenção, processamento, armazenamento e utilização de homoenxertos ósseos. Revista Brasileira de Ortopedia, São Paulo, v. 31, n. 11, p. 895-903, 1996.

FERREIRA, M. P.; ALIEVI, M. M.; BECK, C. A. C.; DALBÓ, I. S.; GONZALEZ, P. C.; NÓBREGA, F. S.; SILVA, L. M.; STÉDILE, R.; SCHERER, S.; ROCHA, J. P. V.; SILVA FILHO, A. P. F.; SVIERK, B.; COSTA, G. Comparison of lyophilization, and freezing in honey as techniques to preserve cortical bone allografts used to repair experimental femoral defects in domestic adult cats. Arquivo Brasileiro de Medicina Veterinária e Zootecnia, Belo Horizonte, v. 64, n. 2, p. 263-273, 2012.

FOSSUM, T. W. Preparation of the operative site. In: SLATTER, D. (Ed.). Small animal surgery. 3. ed. St. Loius: Mobsy Elsevier, 2007. p. 32-37.

FOX, S. M. Cancellous bone grafting in the dog: an overview. Journal of the American Animal Hospital Association, Missouri, v. 20, p. $840-848,1984$.

GAIGA, L. H.; SCHOSSLER, J. E. W. Osteossíntese de úmero por xenoenxerto ósseo preservado em mel em pombos domésticos (Columba livia). Ciência Rural, Santa Maria, v. 33, n. 4, p. 709715, 2003.

GIANNOUDIS, P. V.; EINHORN, T. A.; MARSH, D. Fracture healing: the Diamond concept. Injury, Amsterdam, v. 4, p. S3-S6, 2007.

GIOSO, M. A.; BENITES, N. R.; KÄMPF, G. Análise microbiológica de ossos de cães conservados por longo período de tempo na glicerina a $98 \%$ à temperatura ambiente, objetivando a extertia óssea. Acta Cirurgica Brasileira, São Paulo, v. 17, n. 4, p. 242-246, 2002.

GOLDBERG, V. M.; STEVENSON, S. Natural history of autografts and allografts. Clinical Orthopaedics and Related Research, New York, n. 225, p. 7-16, 1987.

HOSTETTER, G.; COLLINS, E.; VARLAN, P.; EDEWAARD, E.; HARBACH, P. R.; HUDSON, E. A.; FEENSTRA, K. J.; TURNER, L. M.; BERGHUIS, B. D.; RESAU, J. H.; JEWELL, S. D. Veterinary and human biobanking practices: enhancing molecular sample integrity. Veterinary Pathology, New York, v. 51, n. 1, p. 270-280, 2014.

HUNG, N. N. Basic knowledge of bone grafting. In: ZORZI, A. (Ed.). Bone grafting. Shanghai: Intech, 2012. p. 11-38.

INNES, J. F.; MYINT, P. Veterinary tissue banking and bone transplantation. The Veterinary Record, London, v. 168, n. 13, p. 344-345, 2011.

ISOLA, J. G. M. P.; PÁFARO, V.; DUARTE, C. A.; SANTOS, P. S. P.; MORAES, P. C. Estudo Comparativo de ossos autógeno e xenógeno em rádios de cães - Aspectos clínicos e radiográficos. Revista Científica Eletrônica de Medicina Veterinária, Garça, v. 16, p. 1-11, 2011.

JOHNSON, A. L.; HULSE, D. A. Fundamentals of orthopedic surgery and fracture management. In: FOSSUM, T. W. (Ed.). Small animal surgery. 2 ed. St. Louis: Mosby, 2002. p. 848-853.

JUNQUEIRA, L. C; CARNEIRO, J. Histologia básica. 12. ed. Rio de Janeiro: Guanabara Koonan, 2013. 538 p.
KAKIUCHI, M.; ONO, K.; NISHIMURA, A.; SHIOKAWA, H. Preparation of bank bone using defatting, freeze-drying and sterilization with ethylene oxide gas. Part 1. Experimental evaluation of its efficacy and safety. International Orthopaedics, Berlin, v. 20, n. 3, p. 142-146, 1996.

KAVEH, K.; IBRAHIM, R.; BAKAR, M. Z. A.; IBRAHIM, T. A. Bone grafting and bone grafts substitutes. Journal of Animal and Veterinarian Advances, Taiwan, v. 9, n. 6, p. 1055-1067, 2010.

LARSSON, S. Calcium phosphates: what is the evidence? Journal of Orthopaedic Trauma, New York, v. 24, n. 1, p. S41-5, 2010.

LEE, K. W.; WANG, S.; LU, L.; JABBARI, E.; CURRIER, B. L.; YASZEMSKI, M. J. Fabrication and characterization of poly (propylene fumarate) scaffolds with controlled pore structures using 3-dimensional printing and injection molding. Tissue Engineering, New York, v. 12, n. 10, p. 2801-2811, 2006.

LUCARELLI, E.; DONATI, D.; CENACCHI, A.; FORNASARI, P. $\mathrm{M}$. Bone reconstruction of large defects using bone marrow derived autologous stem cells. Transfusion and Apheresis Science, Oxford, v. 30, n. 2, p. 169-174, 2004.

LUCHESE, A. C.; DECHECHI, E. D. Desenvolvimento tecnológico do processo de liofilização. In: SEMINÁRIO DE INICIAÇÃO CIENTÍFICA, MOSTRA DE PESQUISA E E JORNADA DE BIOÉTICA XI, V, 2003, Curitiba. Abais..., Curitiba: PUCPR, 2003. Versão eletrônica.

MARTIN, I.; RIBOLDI, S. A.; JAKOB, M.; WENDT, D. SnapShot: bioreactors systems in tissue engineering (TE) \& regenerative medicine (RM). Biomaterials, Pennsylvania, v. 31, n. 11, p. 31143115, 2010.

MARX, R. E.; WONG, M. E. A technique for the compression and carriage of autogenous bone during bone grafting procedures. Journal of Oral and Maxillofacial Surgery, London, v. 45, n. 11, p. $988-989,1987$.

MATASSI, F.; NISTRI, L.; PAEZ, D. C.; INNOCENTI, M. New biomaterials for bone regeneration. Clinical Cases in Mineral and Bone Metabolism, Rome, v. 8, n. 1, p. 21-24, 2011.

MILLIS, D. L.; MARTINEZ, S. A. Enxertos ósseos. In: SLATTER, D, H. (Ed.). Manual de cirurgia de pequenos animais. 3 ed. São Paulo: Manole, 2007. p. 1875-1891.

MIRANDA, E. S.; CARDOSO, F. T. S.; MEDEIROS FILHO, J. F. DE; BARRETO, M. D'A. R.; TEIXEIRA, R. M. DE M.; WANDERLEY, A. L.; FERNANDES, K. E. Estudo experimental comparativo no uso de enxerto ósseo orgânico e inorgânico no reparo de fraturas cirúrgicas em rádio de coelhos. Acta Ortopédica Brasileira, São Paulo, v. 13, n. 5, p. 245-248, 2005.

PINTO JR, H. S. P.; ALVARENGA, J.; IWASAKI, M. Banco de ossos: coleta, preservação e implante em cães. A Hora Veterinária, Porto Alegre, v. 15, p. 33-37, 1995.

RAPPETI, J. C. S.; PIPPI, N. L.; BRAGA, F. DE V. A.; SOUZA, G. S. DE; COELHO, G. D.; PIGATTO, G. M.; NOVOSAD, D.; HECKLER, M. C. T.; KROLIKOWSKI, G.; AMÊNDOLA, G.; GODOY, C.; CARDONA, R. O. C. Homoimplante de costela conservada em solução supersaturada de açúcar a $300 \%$ ou em açúcar in natura na reconstituição experimental de costelas em gatos. Ciência Rural, Santa Maria, v. 37, n. 6, p. 1712-1718, 2007. ROMAGNOLI, C.; BRANDI, M. Adipose mesenchymal stem cells in the field of bone tissue engineering. World Journal of Stem Cells, Beijing, v. 6, n. 2, p. 144-152, 2014. 
ROOS, M. V.; CAMISA JR., A.; MICHELIN, A. F. Procedimentos de um banco de ossos e a aplicabilidade dos enxertos por ele proporcionados. Acta Ortopédica Brasileira, São Paulo, v. 8, n. 3, p. 122-127, 2000.

SANTOS, A. A.; MIRANDA, C. D. O.; ALVES, M. T. S.; FALOPPA, F. O papel da proteína morfogenética óssea na reparação do tecido ósseo. Acta Ortopédica Brasileira, São Paulo, v. 13, n. 4, p. 194-195, 2005.

SANTOS, F. C.; RAHAL, S. C. Enxerto ósseo esponjoso autólogo em pequenos animais. Ciência Rural, Santa Maria, v. 34, n. 6, p. 1969-1975, 2004.

SCHENA III, C. J. The procurement of cancellous bone for grafting in small animal orthopedic surgery: a review of instrumentation, technique, and pathophysiology. American Animal Hospital Association, Missouri, v. 19, p. 695-701, 1983.

STEVENSON, S. Enxertos ósseos. In: SLATTER, D. (Ed.). Manual de cirurgia de pequenos animais. 2. ed. São Paulo: Manole, 1998. p. 2006-2017.
TABATA, Y. Biomaterial technology for tissue engineering applications. Journal of the Royal Society Interface, Pennsylvania v. 6, p. S311-S324, 2009.

TANAKA, H.; MAEDA, K.; OKITA, Y. Transplantation of the cryopreserved tracheal allograft in growing rabbits. Journal of Pediatric Surgery, New York, v. 38, n. 12, p. 1707-1711, 2003.

WADSWORTH, P. L.; HENRY, W. B. Entire segment cortical bone transplant. Journal of the American Animal Hospital Association, South Bend, v. 12, n. 6, p. 741-745, 1976.

WEIGEL, J. Bone grafing. In: BOJRAB, J. M. (Ed.). Disease mechanisms in small animal surgery. 2. ed. Philadelphia: Lea \& Febiger, 1993. p. 678-685.

ZABEU, J. L. A.; MERCADANTE, M. T. Substitutos ósseos comparados ao enxerto ósseo autólogo em cirurgia ortopédica: revisão sistemática da literatura. Revista Brasileira de Ortopedia, São Paulo, v. 43, n. 3, p. 59-68, 2008.

ZASACKI, W. The efficacy of application of lyophilized, radiationsterilized boné graft in orthopaedic surgery clinical. Orthopaedics and Related Research, Philadelphia, v. 272, p. 82-87, 1991. 